\title{
Design, synthesis, and biological evaluation of 2-(4-(methylsulfonyl) phenyl) indole derivatives with promising COX-2 inhibitory activity
}

\author{
Ahmed M. M. Shaker ${ }^{1 *}$, Eman K. A. Abdelall², Khaled R. A. Abdellatif ${ }^{2,3}$, Hamdy M. Abdel-Rahman ${ }^{1,4}$ \\ ${ }^{1}$ Department of Pharmaceutical Chemistry, Faculty of Pharmacy, Nahda University, Beni-Suef, Egypt. \\ ${ }^{2}$ Department of Organic Chemistry, Faculty of Pharmacy, Beni-Suef University, Beni-Suef, Egypt. \\ ${ }^{3}$ Pharmaceutical Sciences Department, IbnSina National College for Medical Studies, Jeddah, Kingdom of Saudi Arabia. \\ ${ }^{4}$ Department of Medicinal Chemistry, Faculty of Pharmacy, Assiut University, Assiut, Egypt.
}

\begin{tabular}{l}
\hline ARTICLE INFO \\
\hline Received on: 11/08/2018 \\
Accepted on: 17/09/2018 \\
Available online: 30/11/2018 \\
\\
\hline Key words: \\
Indole, indomethacin, \\
anti-inflammatory activity, \\
selective COX-2, molecular \\
modeling.
\end{tabular}

\begin{tabular}{l}
\hline ABSTRACT \\
\hline A series of 2-(4-(methylsulfonyl)phenyl)-1-substituted-indole derivatives 4a-f was designed and synthesized as \\
indomethacin analogs; All synthesized compounds were assessed for their in vitro COX-2 inhibition effect as well as \\
in vivo anti-inflammatory activity using indomethacin as a reference drug. All synthesized compounds showed good \\
anti-inflammatory activity and more selectivity for COX-2 inhibition. A molecular modeling study was carried out and \\
the results were compatible with that derived from in vitro COX-2 inhibition assays.
\end{tabular}
in the results were compatible with that derived from in vitro COX-2 inhibition assays.

\section{INTRODUCTION}

The pharmacological effect of non-steroidal antiinflammatory drugs (NSAIDs) is due to their inhibition of cyclooxygenase enzymes that catalyze arachidonic acid biotransformation to the inflammatory mediators (prostaglandins and thromboxanes) (Brune and Patrignani, 2015; Bruno et al., 2014; Pountos et al., 2012). There are two types of cyclooxygenase enzyme; constitutive form (COX-1), which is responsible for the maintenance of physiological functions such as protection of gastric mucosa and kidney (Jutti Levita et al., 2010; Kirkby et al., 2016; Van Breemen et al., 2011) and the inducible form (COX2) which is produced due to inflammatory stimuli (Pathak et al., 2014; Regulski et al., 2016).

\section{"Corresponding Author}

Ahmed M. M. Shaker, Department of Pharmaceutical Chemistry, Faculty of Pharmacy, Nahda University, Beni-Suef, Egypt.

E-mail:ph.ahmedshaker@yahoo.com
Peptic ulcer and bleeding are the major side effects of traditional NSAIDs such as aspirin I and indomethacin II (Wehling, 2014), that is due to non-selective inhibition of COX enzyme, so selective COX-2 inhibitor drugs such as valdecoxib III, celecoxib $\mathbf{I V}$, and rofecoxib $\mathbf{V}$ relief inflammation and pain without any gastric problems (Sostres et al., 2013) (Fig. 1). Cardiovascular side effects associated with the use of selective COX-2 inhibitors led to the withdrawal of rofecoxib and valdecoxib from the market (Harirforoosh et al., 2014).

Indomethacin is effective NSAIDs which used in the treatment of osteoarthritis and ankylosing spondylitis (Kaur et al., 2012). It is one of the most ulcerogenic NSAIDs (Bandgar et al., 2011) due to its high selectivity for COX-1 inhibition.

From the previous literature, there are two strategies to overcome the gastric side effects of indomethacin; the first one is the presence of nitric oxide donating group attached to indomethacin which protects gastric mucosa and also decreases cardiovascular problems associated with selective COX-2 inhibitors (coxibs) (Abdellatif et al., 2016b; Lakshman et al., 2016), the second strategy aimed to maintain the great 
<smiles>CC(=O)Oc1ccccc1C(=O)O</smiles><smiles>COc1ccc2c(c1)c(CC(=O)O)c(C)n2C(=O)c1ccc(Cl)cc1</smiles>

Aspirin

I<smiles>Cc1onc(-c2ccccc2)c1-c1ccc(S(N)(=O)=O)cc1</smiles>

Valdecoxib

III

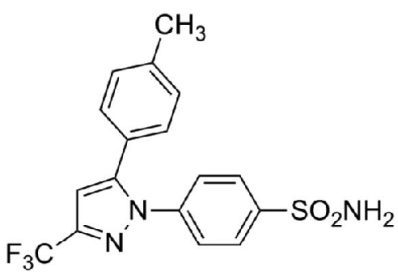

Celecoxib IV<smiles>COS(=O)(=O)c1ccc(C2=C(c3ccccc3)C(=O)OC2)cc1</smiles>

Rofecoxib $\checkmark$

Figure 1. Chemical structures of some traditional non-selective NSAIDs (I and II) and selective cyclooxygenase-2 (COX-2) inhibitor drugs (III, IV, and V).

activity of indomethacin by keeping the main structure of indomethacin and modifying of the structure by adding side groups to try to increase the selectivity for COX-2 inhibition and decrease its acidic nature.

The current work presents synthesis, in vitro cyclooxygenase (COX) inhibition screening, in vivo antiinflammatory activity study, and molecular docking for a series of synthesized compounds as indomethacin analogs in which: (i) chlorobenzoyl moiety of indomethacin at position 1, which is important for anti-inflammatory activity (Chowdhury et al., 2010) was replaced by 4 -substituted benzyl moiety (4a-f); (ii) replacement of methyl group in position 2 by 4 -methyl sulphonyl phenyl moiety, which increases interaction and subsequently increases selectivity with hydrophobic residue of
COX-2 active site; (iii) removal of acidic center $\left(\mathrm{CH}_{2} \mathrm{COOH}\right)$ moiety in position 3 and replaced by hydrogen atom which will decrease acidity and ulcerogenic effect of resulted compounds; and (iv) methoxy group in position 5 was replaced with $\mathrm{H}, \mathrm{CH}_{3}$, or F (Fig. 2).

\section{MATERIALS AND METHODS}

\section{Instrument and reagents}

Melting points were determined on a Thomas-Hoover capillary apparatus and were uncorrected. Infrared (IR) spectra were recorded as films on $\mathrm{NaCl}$ plates using a Nicolet 550 Series II Magna FT-IR spectrometer. Thin-layer chromatography (TLC) (on aluminum plates coated with silica gel 60 F254, 0.25-mm thickness; Merck, Darmstadt, Germany) was used for checking the progress of

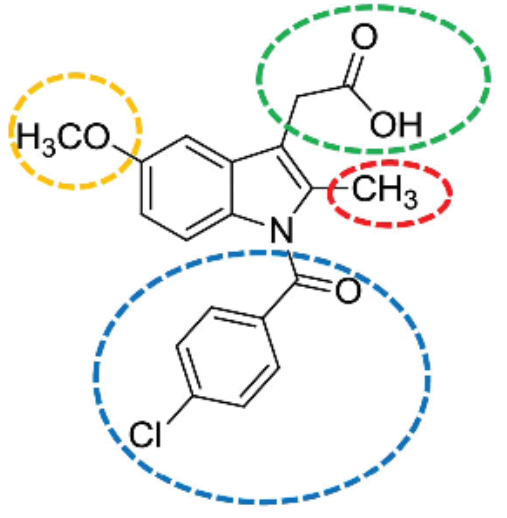

Indomethacin (2)

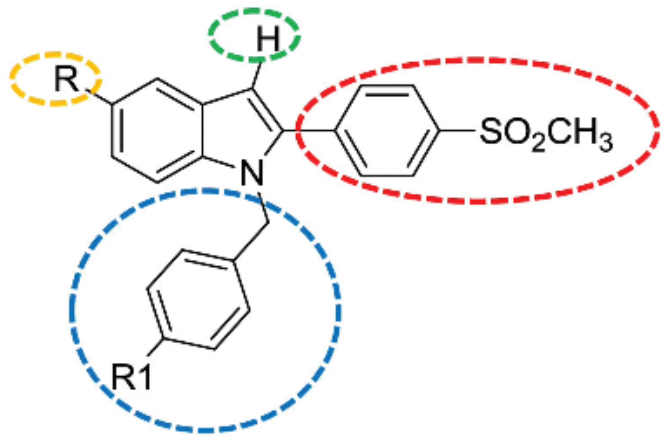

$4 a-f$

Figure 2. Chemical structures of the traditional NSAID indomethacin (2) and the designed indomethacin analogs 4a-f. 
reactions, purity, and homogeneity of the synthesized compounds. UV radiation was used as the visualizing agent. ${ }^{1} \mathrm{H}$ NMR spectra were measured on a Bruker Avance III $400 \mathrm{MHz}$ for ${ }^{1} \mathrm{H}$ (Bruker AG, Switzerland), Faculty of Pharmacy, Beni-Suef University, Egypt in dimethylsulfoxide (DMSO)- $d_{6}$ with TMS as the internal standard, in which $J$ (coupling constant) values are estimated in Hertz $(\mathrm{Hz})$ and chemical shifts were recorded in ppm on $\delta$ scale. ${ }^{13} \mathrm{C}$ NMR spectra were carried out on Burker $100 \mathrm{MHZ}$ spectrophotometer, Faculty of Pharmacy, Beni-Suef University, Egypt, using TMS as internal standard and chemical shifts were recorded in ppm on $\delta$ scale. Elemental analyses for $\mathrm{C}, \mathrm{H}$, and $\mathrm{N}$ were performed on PerkinElmer 2400 analyzer (Perkin-Elmer, Norwalk, CT) at the elemental analyses unit of $\mathrm{Al}$ Azhar University, Egypt and all synthesized compounds were ranged $\pm 0.4 \%$ of the theoretical values. All other reagents, from the Aldrich Chemical Company (Milwaukee, WI), were used without additional purification. 4-methylthioacetophenone and 4-methylsulfonylacetophenone were prepared according to a previous procedure (Raju and Basavaraju, 2013; Yu et al., 2012).

General procedure for synthesis of 5-substituted-2-(4(methylsulfonyl)phenyl)-1-substituted-indole 4a-d

A solution of 5-substituted-2-(4-(methylsulfonyl) phenyl)-1-substituted-indole $(\mathbf{3 a}-\mathbf{c})(2.5 \mathrm{mmol})$ and $\mathrm{NaH}(0.1 \mathrm{~g}$, $4.5 \mathrm{mmol})$ in dry DMF (N,N-Dimethylformamide) $(5 \mathrm{ml})$ was stirred for 30 minutes at room temperature. Then slowly add the substituted benzyl chloride at zero temperature and allow the reaction mixture to stir at room temperature overnight. The reaction mixture was poured into ice cold water, the precipitated solid was filtered, dried, and recrystallized from ethanol (yield: 50\%-75\%).

\section{1-Benzyl-2-(4-(methylsulfonyl)phenyl)-1H-indole (4a)}

Brown solid; Yield $58 \%$; mp $111^{\circ} \mathrm{C}-113^{\circ} \mathrm{C}$; IR (KBr) 3034 (CH aromatic) 2925, 2860 (CH aliphatic), 1312, 1149 $\left(\mathrm{SO}_{2}\right) \mathrm{cm}^{-1} ;{ }_{1}^{1} \mathrm{H}$ NMR (DMSO- $\left.d_{6}\right) \delta 3.26\left(s, 3 \mathrm{H}, \mathrm{SO}_{2} \mathrm{CH}_{3}\right), 5.53(s$, $\left.2 \mathrm{H}, \mathrm{CH}_{2}\right), 6.83(\mathrm{~s}, 1 \mathrm{H}$, indole $\mathrm{H}-3), 6.89(d, 2 \mathrm{H}, J=8 \mathrm{~Hz}$, benzyl H-2, H-6), 7.09-7.24 ( $m, 5 \mathrm{H}$, benzyl H-3, H-4, H-5, indole H-5, indole H-6), $7.19(t, 1 \mathrm{H}, J=8 \mathrm{~Hz}$, indole $\mathrm{H}-5), 7.18-7.3(\mathrm{~m}$, $3 \mathrm{H}$, benzyl H-3, H-4, H-5), $7.42(d, 1 \mathrm{H}, J=8 \mathrm{~Hz}$, indole $\mathrm{H}-4)$, $7.66(d, 1 \mathrm{H}, J=8 \mathrm{~Hz}$, indole $\mathrm{H}-7), 7.79(d, 2 \mathrm{H}, J=8 \mathrm{~Hz}$, phenyl $\mathrm{H}-3, \mathrm{H}-5), 8.00\left(d, 2 \mathrm{H}, J=8 \mathrm{~Hz}\right.$, phenyl H-2, H-6); ${ }^{13} \mathrm{C} \mathrm{NMR}$ $\left(\mathrm{DMSO}-d_{6}\right) \delta 43.92\left(\mathrm{SO}_{2} \mathrm{CH}_{3}\right), 47.41\left(\mathrm{CH}_{2}\right), 104.57,111.31$, $119.93,121.18,122.98,126.26,127.63,127.70,127.90,128.12$, 129.87, 131.50, 136.94, 137.47, 137.61, 139.73, and 140.42. Anal. Calcd for $\mathrm{C}_{22} \mathrm{H}_{19} \mathrm{NO}_{2} \mathrm{~S}$ : C, 73.10; H, 5.30; N, 3.88. Found: C, 72.94; H, 5.43; N, 4.01.

\section{1-(4-Chlorobenzyl)-2-(4-(methylsulfonyl)phenyl)-1H-indole (4b)}

Yellow solid; Yield 55\%; mp $105^{\circ} \mathrm{C}-106^{\circ} \mathrm{C}$; IR (KBr) 3036 (CH aromatic)2926, 2857 ( $\mathrm{CH}$ aliphatic), 1312, $1150\left(\mathrm{SO}_{2}\right)$ $\mathrm{cm}^{-1} ;{ }^{1} \mathrm{H}$ NMR (DMSO- $\left.d_{6}\right) \delta 3.26\left(s, 3 \mathrm{H}, \mathrm{SO}_{2} \mathrm{CH}_{3}\right), 5.53(s, 2 \mathrm{H}$, $\left.\mathrm{CH}_{2}\right), 6.84(s, 1 \mathrm{H}$, indole $\mathrm{H}-3), 6.89(d, 2 \mathrm{H}, J=8 \mathrm{~Hz}$, benzyl H-2, H-6), $7.12(t, 1 \mathrm{H}, J=6 \mathrm{~Hz}$, indole H-6), $7.19(t, 1 \mathrm{H}, J=8 \mathrm{~Hz}$, indole $\mathrm{H}-5), 7.3(d, 2 \mathrm{H}, J=8 \mathrm{~Hz}$, benzyl H-3, H-5), $7.43(d, 1 \mathrm{H}$, $J=8 \mathrm{~Hz}$, indole H-4), $7.66(d, 1 \mathrm{H}, J=8 \mathrm{~Hz}$, indole H-7), 7.77 $(d, 2 \mathrm{H}, J=8 \mathrm{~Hz}$, phenyl H-3, H-5), $8.00(d, 2 \mathrm{H}, J=8 \mathrm{~Hz}$, phenyl $\mathrm{H}-2, \mathrm{H}-6) ;{ }^{13} \mathrm{C}$ NMR (DMSO- $\left.d_{6}\right) \delta 43.91\left(\mathrm{SO}_{2} \mathrm{CH}_{3}\right), 46.80\left(\mathrm{CH}_{2}\right)$, $104.73,111.48,120.84,121.24,123.09,127.92,128.13,128.24$, $129.07,129.87,132.19,137.44,137.51,138.63,139.63$, and
140.46. Anal. Calcd for $\mathrm{C}_{22} \mathrm{H}_{18} \mathrm{ClNO}_{2} \mathrm{~S}: \mathrm{C}, 66.74 ; \mathrm{H}, 4.58 ; \mathrm{N}, 3.54$. Found: C, 66.58; H, 4.66; N, 3.69.

\section{1-Benzyl-5-methyl-2-(4-(methylsulfonyl)phenyl)-1H-indole (4c)}

Brown solid; Yield $65 \%$; mp $131^{\circ} \mathrm{C}-133^{\circ} \mathrm{C}$; IR (KBr) 3035 (CH aromatic) 2926, 2865 (CH aliphatic), 1,312, 1,149 $\left(\mathrm{SO}_{2}\right) \mathrm{cm}^{-1} ;{ }^{1} \mathrm{H}$ NMR (DMSO- $\left.d_{6}\right) \delta 2.39\left(s, 3 \mathrm{H}, \mathrm{CH}_{3}\right), 3.26(s, 3 \mathrm{H}$, $\left.\mathrm{SO}_{2} \mathrm{CH}_{3}\right), 5.51\left(s, 2 \mathrm{H}, \mathrm{CH}_{2}\right), 6.75(s, 1 \mathrm{H}$, indole $\mathrm{H}-3), 6.86(d, 2 \mathrm{H}$, $J=4 \mathrm{~Hz}$, benzyl H-2, H-6), $7.00(d, 1 \mathrm{H}, J=8 \mathrm{~Hz}$, indole H-6), 7.23-7.32 ( $m, 3 \mathrm{H}$, benzyl H-3, H-4, H-5), 7.43 ( $s, 1 \mathrm{H}$, indole H-4), $7.64(d, 1 \mathrm{H}, J=8 \mathrm{~Hz}$, indole $\mathrm{H}-7), 7.78(d, 2 \mathrm{H}, J=8 \mathrm{~Hz}$, phenyl $\mathrm{H}-3, \mathrm{H}-5), 7.99\left(d, 2 \mathrm{H}, J=8 \mathrm{~Hz}\right.$, phenyl H-2, H-6); ${ }^{13} \mathrm{C}$ NMR $\left(\mathrm{DMSO}-d_{6}\right) \delta 21.54\left(\mathrm{CH}_{3}\right), 43.91\left(\mathrm{SO}_{2} \mathrm{CH}_{3}\right), 47.44\left(\mathrm{CH}_{2}\right), 104.15$, $111.31,120.69,124.61,126.30,127.58,127.88,128.36,129.04$, 129.39, 129.73, 137.28, 137.69, 138.58, 139.74, and 140.29. Anal. Calcd for $\mathrm{C}_{23} \mathrm{H}_{20} \mathrm{ClNO}_{2} \mathrm{~S}$ : C, 73.57; H, 5.64; N, 3.73. Found: C, $73.8 ; \mathrm{H}, 5.72 ; \mathrm{N}, 3.89$.

\section{1-(4-Chlorobenzyl)-5-methyl-2-(4-(methylsulfonyl)phenyl)- 1H-indole (4d)}

Buff solid; Yield $70 \%$; mp $125^{\circ} \mathrm{C}-126^{\circ} \mathrm{C}$; IR (KBr) 3035 (CH aromatic) 2926, 2868 (CH aliphatic), 1,312, 1,151 ( $\left.\mathrm{SO}_{2}\right) \mathrm{cm}^{-1}$; ${ }^{1} \mathrm{H}$ NMR (DMSO- $\left.d_{6}\right) \delta 2.38\left(s, 3 \mathrm{H}, \mathrm{CH}_{3}\right), 3.24\left(s, 3 \mathrm{H}, \mathrm{SO}_{2} \mathrm{CH}_{3}\right)$, $5.48\left(s, 2 \mathrm{H}, \mathrm{CH}_{2}\right), 6.74(s, 1 \mathrm{H}$, indole $\mathrm{H}-3), 6.85(d, 2 \mathrm{H}, J=12 \mathrm{~Hz}$, benzyl H-2, H-6), $7.00(d, 1 \mathrm{H}, J=8 \mathrm{~Hz}$, indole $\mathrm{H}-6), 7.28(d, 2 \mathrm{H}$, $J=8 \mathrm{~Hz}$, benzyl H-3, H-5), $7.43(s, 1 \mathrm{H}$, indole H-4), $7.61(d, 1 \mathrm{H}, J$ $=8 \mathrm{~Hz}$, indole $\mathrm{H}-7), 7.75(d, 2 \mathrm{H}, J=8 \mathrm{~Hz}$, phenyl $\mathrm{H}-3, \mathrm{H}-5), 7.98$ $\left(d, 2 \mathrm{H}, J=12 \mathrm{~Hz}\right.$, phenyl H-2, H-6); ${ }^{13} \mathrm{C}$ NMR (DMSO- $\left.d_{6}\right) \delta 21.53$ $\left(\mathrm{CH}_{3}\right), 43.91\left(\mathrm{SO}_{2} \mathrm{CH}_{3}\right), 46.84\left(\mathrm{CH}_{2}\right), 104.33,111.24,120.75$, 124.72 , 127.91, 128.21, 128.38, 129.04, 129.53, 129.73, 132.14, $137.20,137.53,137.62,139.64,140.34 . \delta 21.53\left(\mathrm{CH}_{3}\right), 43.91$ $\left(\mathrm{SO}_{2} \mathrm{CH}_{3}\right), 46.84\left(\mathrm{CH}_{2}\right), 104.33,111.24,120.75,124.72,127.91$, $128.21,128.38,129.04,129.53,129.73,132.14,137.20,137.53$, 137.62, 139.64, and 140.34. Anal. Calcd for $\mathrm{C}_{23} \mathrm{H}_{20} \mathrm{ClNO}_{2} \mathrm{~S}: \mathrm{C}$, $67.39 ; \mathrm{H}, 4.92 ; \mathrm{N}, 3.42$. Found: C, 67.21; H, 4.85; N, 3.60.

\section{1-Benzyl-5-fluoro-2-(4-(methylsulfonyl)phenyl)-1H-indole (4e)}

Yellow solid; Yield $68 \%$; mp $115^{\circ} \mathrm{C}-116^{\circ} \mathrm{C}$; IR (KBr) 3029 (CH aromatic) 2926, 2856 (CH aliphatic), 1,312, 1,149 ( $\left.\mathrm{SO}_{2}\right)$ $\mathrm{cm}^{-1}$; ${ }^{1} \mathrm{H}$ NMR (DMSO- $\left.d_{6}\right) \delta 3.27\left(s, 3 \mathrm{H}, \mathrm{SO}_{2} \mathrm{CH}_{3}\right), 5.53(s, 2 \mathrm{H}$, $\left.\mathrm{CH}_{2}\right), 6.82(s, 1 \mathrm{H}$, indole H-3), $6.87(d, 2 \mathrm{H}, J=8 \mathrm{~Hz}$, benzyl H-2, H-6), $7.03(d, 1 \mathrm{H}, J=8 \mathrm{~Hz}$, indole H-6), 7.19-7.23 ( $m$, 3H, benzyl $\mathrm{H}-3, \mathrm{H}-4, \mathrm{H}-5), 7.41-7.47$ ( $m, 2 \mathrm{H}$, indole $\mathrm{H}-4, \mathrm{H}-7), 7.8(d, 2 \mathrm{H}$, $J=8 \mathrm{~Hz}$, phenyl H-3, H-5), $8.01(d, 2 \mathrm{H}, J=12 \mathrm{~Hz}$, phenyl H-2, $\mathrm{H}-6) ;{ }^{13} \mathrm{C}$ NMR (DMSO- $\left.d_{6}\right) \delta 43.87\left(\mathrm{SO}_{2} \mathrm{CH}_{3}\right), 47.58\left(\mathrm{CH}_{2}\right), 104.44$, $105.61,111.00,112.73,126.32,127.70,128.81,129.97,131.55$, 135.36, 137.26, 138.27, 140.70, 141.8, 156.82, and 159.14. Anal. Calcd for $\mathrm{C}_{22} \mathrm{H}_{18} \mathrm{FNO}_{2} \mathrm{~S}$ : C, 69.64; H, 4.78; N, 3.69. Found: C, 69.78; H, 4.90; N, 4.01.

\section{1-(4-Chlorobenzyl)-5-fluoro-2-(4-(methylsulfonyl)phenyl)- 1H-indole (4f)}

Yellow solid; Yield $75 \%$; mp $108^{\circ} \mathrm{C}-109^{\circ} \mathrm{C}$; IR (KBr) 3029 (CH aromatic) 2926, 2856 (CH aliphatic), 1,312, 1,150 ( $\left.\mathrm{SO}_{2}\right)$ $\mathrm{cm}^{-1} ;{ }^{1} \mathrm{H}$ NMR (DMSO- $\left.d_{6}\right) \delta 3.26\left(s, 3 \mathrm{H}, \mathrm{SO}_{2} \mathrm{CH}_{3}\right), 5.53\left(s, 2 \mathrm{H}, \mathrm{CH}_{2}\right)$, $6.82(s, 1 \mathrm{H}$, indole $\mathrm{H}-3), 6.87(d, 2 \mathrm{H}, J=8 \mathrm{~Hz}$, benzyl H-2, H-6), 7.03 $(d, 1 \mathrm{H}, J=8 \mathrm{~Hz}$, indole H-6), $7.3(d, 2 \mathrm{H}, J=8 \mathrm{~Hz}$, benzyl H-3, H-5), $7.43(m, 2 \mathrm{H}$, indole $\mathrm{H}-4, \mathrm{H}-7), 7.78(d, 2 \mathrm{H}, J=8 \mathrm{~Hz}$, phenyl $\mathrm{H}-3$, 
$\mathrm{H}-5), 8.01\left(d, 2 \mathrm{H}, J=8 \mathrm{~Hz}\right.$, phenyl H-2, H-6); ${ }^{13} \mathrm{C}$ NMR (DMSO- $d$ ) $\delta 43.88\left(\mathrm{SO}_{2} \mathrm{CH}_{3}\right), 46.98\left(\mathrm{CH}_{2}\right), 104.63,105.70,111.12,112.67$, $127.95,128.23$, 129.09, 129.97, 132.26, 135.27, 137.10, 137.29, 140.72, 141.38, 156.87, and 159.19. Anal. Calcd for $\mathrm{C}_{22} \mathrm{H}_{17} \mathrm{ClFNO}_{2} \mathrm{~S}$ : C, 63.84; H, 4.14; N, 3.38. Found: C, 63.90; H, 4.21; N, 3.42.

\section{Biological Evaluation}

In vivo anti-inflammatory activity Animals

Wistar albino male rats weighing (120-140 g; received from the animal house of Nahda University, Beni-seuf, Egypt) were divided into eight groups in cages (five per cage) at laboratory temperature $25^{\circ} \mathrm{C} \pm 1{ }^{\circ} \mathrm{C}$ with $60 \% \pm 10 \%$ humidity with the presence of food and water source. Procedures of animal care and treatments were carried out according to the research ethical committee protocol, Beni-suef University (2014-Beni-suef, Egypt).

\section{COX-1/COX-2 inhibition colorimetric assay}

The kit of colorimetric COX (ovine) Inhibitory Screening Assay (Kit catalog number 760111, Cayman Chemical, Ann Arbor, MI) was used according to the manufacturer's protocol as mentioned earlier (Abdelazeem et al., 2014) to measure the capability of synthesized compounds to inhibit COX-1 and COX2 enzymes. The results are shown in Table 1.

\section{Carrageenan-induced rat paw edema assay}

Group I (negative control) received 5\% DMSO aqueous solution (v/v), Group II received indomethacin as a reference drug (10 mg/kg; po), and the other six groups received compounds $4 \mathbf{a}-\mathbf{f}$ $(10 \mathrm{mg} / \mathrm{kg}$; po) in form of 5\% DMSO aqueous solution.

The treatment began 1 hour before the induction of inflammation. Sub-plantar injection of $0.02 \mathrm{ml}$ of $1 \%$ carrageenan
Table 1. In vitro COX-1 and COX-2 inhibition for compounds $4 \mathbf{a}-\mathbf{f}$ and reference drugs (Indomethacin).

\begin{tabular}{cccc}
\hline \multirow{2}{*}{ Compounds } & \multicolumn{2}{c}{$\begin{array}{c}\text { COX inhibition } \\
\left(\mathbf{I C}_{50} \boldsymbol{\mu M}\right)\end{array}$} & \\
\cline { 2 - 3 } & $\mathbf{C O X}-\mathbf{1}$ & $\mathbf{C O X}-\mathbf{2}$ & \\
\hline $4 \mathrm{a}$ & 9.21 & 0.18 & 51.16 \\
$4 \mathrm{~b}$ & 11.84 & 0.11 & 107.63 \\
$4 \mathrm{c}$ & 8.1 & 0.20 & 40.5 \\
$4 \mathrm{~d}$ & 10.1 & 0.16 & 63.12 \\
$4 \mathrm{e}$ & 8.5 & 0.28 & 30.35 \\
$4 \mathrm{f}$ & 11.5 & 0.15 & 76.6 \\
Indomethacin & 0.039 & 0.49 & 0.079 \\
\hline
\end{tabular}

a Selectivity index (COX-1 $\left.\mathrm{IC}_{50} / \mathrm{COX}-2 \mathrm{IC}_{50}\right)$.

(Sigma-Aldrich, USA) in normal saline was used to induce paw edema. Plethysmometer was used to determine the thickness of paw edema after 1,3 , and 5 hours from carrageenan injection (Abdellatif et al., 2016a).

Anti-inflammatory activity was determined by the percentage of inflammation inhibition of rat paw thickness according to the following equation:

Edema inhibition $(\%)=\left(T_{c}-T_{t} / T_{c}\right) \times 100$

where $T_{t}$ is the mean increase in paw thickness in rats treated with the tested compound;

$T$ is the mean increase in paw thickness in rats of the control group. The results were shown in Table 2.

\section{Molecular modeling and docking}

Molecular operating environment (MOE) version 2014.09 software was used for molecular modeling studies. The structures of

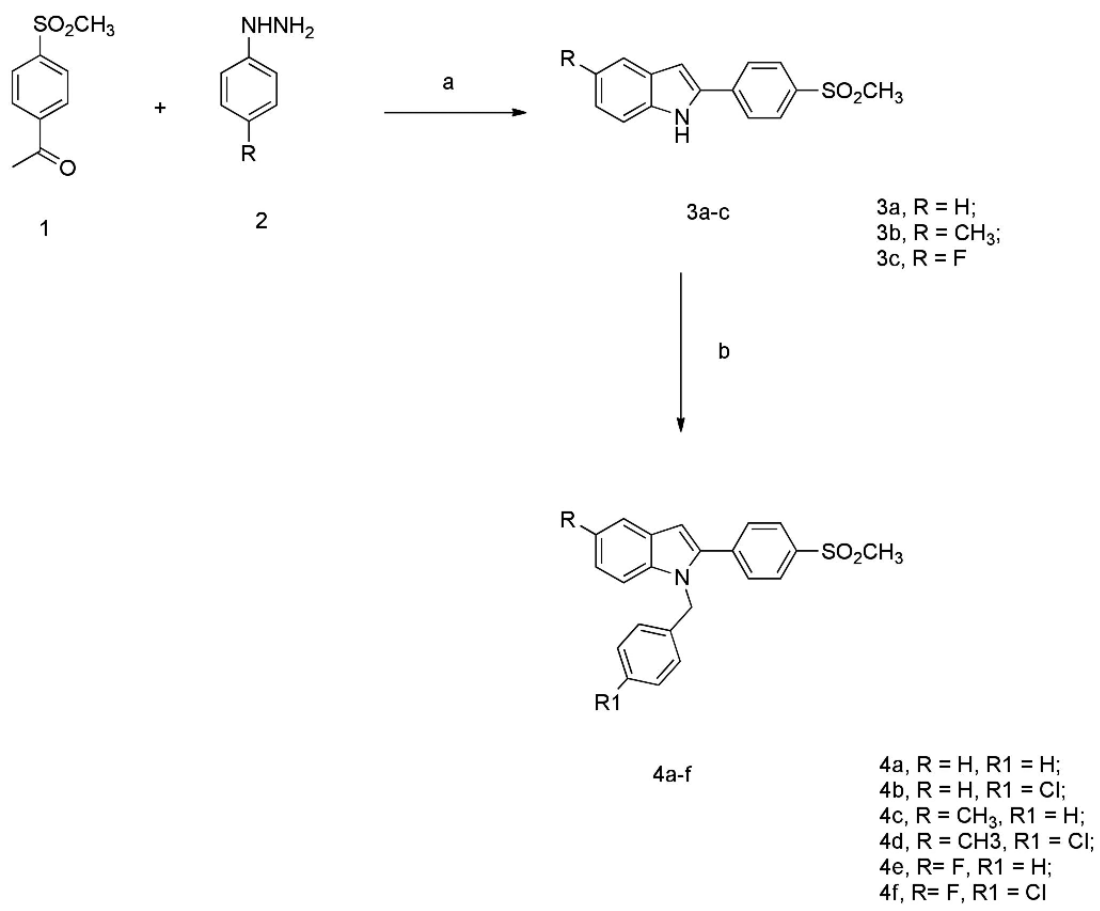

Scheme 1. Reagents and conditions: (a) acetic acid, reflux, 9 hours; (b) 4-substituted benzyl chloride, NaH, DMF, RT, overnight. 
4b and $\mathbf{4 f}$ were prepared using MOE. Valdecoxib crystal structure with the COX-2 active site (PDB: ID 2AW1) was obtained from the protein data bank (PDB; Di Fiore et al., 2006). Preparation of the enzyme for docking by 3D protonation, where hydrogen atoms were added to their standard geometry. The structures of $\mathbf{4 b}$ and $\mathbf{4 f}$ were docked into the COX-2 receptor through MOE-Dock using triangle matcher placement method, London dG scoring function and force field refinement was accomplished on the top 30 poses per each ligand. Re-docking of valdecoxib with 2AW1 active site to validate the docking method. Interactions of amino acids and the lengths of hydrogen bonds were illustrated in Table 3.

\section{RESULTS AND DISCUSSION}

\section{Chemistry}

The synthesized compounds were obtained from a series of reactions demonstrated in Scheme 1. 4-methylsulfonyl acetophenone (1) reacted with substituted phenylhydrazine hydrochloride (2) in acetic acid under Fisher indole synthesis reaction conditions to yield 5-substituted-2-(4-(methylsulfonyl) phenyl)-1-substituted-indole (3a-c) (Abdellatif et al., 2016a; Zarghi et al., 2008). A solution of indole derivatives (3a-c) with substituted benzyl chloride in DMF in presence of $\mathrm{NaH}$ to give desired compounds (4a-f).

All newly synthesized compounds were characterized by IR, ${ }^{1} \mathrm{H} \mathrm{NMR},{ }^{13} \mathrm{C} \mathrm{NMR}$, and elemental analyses. The IR spectra showed two absorption bands at 1,312 and 1,149-1,151 $\mathrm{cm}^{-1}$ corresponding to $\mathrm{SO}_{2}$. Also, ${ }^{1} \mathrm{HNMR}$ spectra showed a singlet peak at $\delta 3.24-3.27$ for $\mathrm{SO}_{2} \mathrm{CH}_{3}$. Finally, ${ }^{13} \mathrm{C}$ NMR spectra showed a peak at $\delta 43.87-43.92$ for $\mathrm{SO}_{2} \mathrm{CH}_{3}$, peak at $\delta 21.53$ for $\mathrm{CH}_{3}$ for compounds $\mathbf{4 c}$ and $\mathbf{4 d}$.

\section{Biological evaluation}

\section{In vitro cyclooxygenase (COX) inhibitory assay}

The obtained data (Table 1) for in vitro COX-1/COX2 inhibitory assay showed that all synthesized compounds with weak selectivity for $\mathrm{COX}-1\left(\mathrm{IC}_{50}=8.1-11.8 \mu \mathrm{M}\right)$ in comparison with indomethacin $\left(\mathrm{IC}_{50}=0.039 \mu \mathrm{M}\right)$.

Otherwise, they are high selectivity of COX-2 $\left(\mathrm{IC}_{50}=0.11-0.2 \mu \mathrm{M}\right)$ in comparison with indomethacin $\left(\mathrm{IC}_{50}=0.49 \mu \mathrm{M}\right)$. All compounds with selectivity to COX-2 enzyme (selectivity index $=40.5-107$ ) were more than indomethacin $(\mathrm{SI}=0.079)$. Compound $\mathbf{4 b}$ showed the most inhibitory activity against COX-2 $\left(\mathrm{IC}_{50}=0.11 \mu \mathrm{M}\right.$ and $\left.\mathrm{SI}=107.63\right)$, had a chlorobenzyl and methylsulfonyl moiety which was 1,362 times more selective toward COX-2 isozyme than indomethacin (COX$\left.2 \mathrm{IC}_{50}=0.49 \mu \mathrm{M}, \mathrm{SI}=0.079\right)$.

\section{In vivo anti-inflammatory activity}

The anti-inflammatory activity was monitored for all tested compounds and compared to indomethacin by using the carrageenan-induced rat paw edema test. Results were listed in Table 2.

The results demonstrated that the compounds $\mathbf{4 b}, \mathbf{4 d}$, and 4f with the highest $\mathrm{COX}-2$ inhibition activity $\left(\mathrm{IC}_{50}=0.11,0.17\right.$, and $0.15 \mu \mathrm{M}$, respectively) showed a reduction of inflammation by $93.7 \%, 85.1 \%$, and $90.7 \%$ after 6 hours, respectively, near to indomethacin $(96 \%$ inhibition of inflammation after 6 hours).
Table 2. Anti-inflammatory activities for compounds $\mathbf{4 a - f}$, and reference drug (Indomethacin) in carrageen an-induced rat paw edema test.

\begin{tabular}{cccc}
\hline Compound & \multicolumn{3}{c}{ \% of anti-inflammatory activity (AI) } \\
\cline { 2 - 4 } & $\mathbf{1 ~ h o u r ~}$ & $\mathbf{3}$ hours & $\mathbf{5}$ hours \\
\hline $4 \mathrm{a}$ & 76.2 & 71.9 & 51.9 \\
$4 \mathrm{~b}$ & 93.7 & 93.5 & 84.4 \\
$4 \mathrm{c}$ & 59.4 & 62.1 & 52.7 \\
$4 \mathrm{~d}$ & 85.1 & 87.1 & 54.6 \\
$4 \mathrm{e}$ & 78.5 & 65.5 & 50.3 \\
$4 \mathrm{f}$ & 90.7 & 84.3 & 68.3 \\
Indomethacin & 96 & 96.6 & 70.7 \\
\hline
\end{tabular}

Whilst the compounds $\mathbf{4 a}, \mathbf{4 c}$, and $\mathbf{4 e}$ with COX-2 inhibition activity $\left(\mathrm{IC}_{50}=0.18,0.20\right.$, and $0.28 \mu \mathrm{M}$, respectively) showed good anti-inflammatory activity $(76.2 \%, 59.4 \%$, and $78.5 \%$ inhibition of inflammation after 6 hours, respectively) in comparison with indomethacin $(96 \%$ inhibition of inflammation after 6 hours).

From the obtained results, we can conclude the following structure-activity relationships of the synthesized compounds as follows: (i) presence of phenyl methyl sulfonyl $\left(\mathrm{SO}_{2} \mathrm{Me}\right)$ moiety increase COX-2 inhibition activity; (ii) replacement of benzoyl group of indomethacin with benzyl group maintains antiinflammatory activity; and (iii) all p-chloro benzyl derivatives have anti-inflammatory activity higher than non-substituted benzyl derivatives.

\section{Molecular modeling}

The molecular modeling study was performed using COX-2 crystal structure (PDB ID: 2AW1) (Di Fiore et al., 2006) to show the binding mode of synthesized compounds to the COX2 active site.

Table 3 shows the results of computational docking of compounds $\mathbf{4 b}, \mathbf{4 f}$, indomethacin II, and valdecoxib III as a ligand for COX-2 enzyme using MOE 2014.09 modeling software.

Valdecoxib interacted with COX-2 through five hydrogen bonds as follows: (i) $\mathrm{NH}_{2}$ with His119 (2.74 $\left.\mathrm{A}^{\circ}\right)$, (ii) $\mathrm{NH}_{2}$ with Thr199 $\left(3.46 \mathrm{~A}^{\circ}\right)$, (iii) $\mathrm{SO}_{2}$ with Leu199 $\left(3.12 \mathrm{~A}^{\circ}\right.$ ), (iv) $\mathrm{SO}_{2}$ with Thr199 $\left(2.77 \mathrm{~A}^{\circ}\right)$, and (v) $\mathrm{NH}_{2}$ with His94 $\left(2.89 \mathrm{~A}^{\circ}\right)$.

On the other hand, compound $\mathbf{4 b}$ had four hydrogen bonding interactions as follows: (i) $\mathrm{SO}_{2}$ with $\mathrm{His} 94\left(2.85 \mathrm{~A}^{\circ}\right)$, (ii) $\mathrm{SO}_{2}$ with His96 (3.39 $\left.\mathrm{A}^{\circ}\right)$, (iii) $\mathrm{SO}_{2}$ with Thr199 (3.35 $\mathrm{A}^{\circ}$ ), and (iv) $\mathrm{SO}_{2}$ with $\mathrm{Thr} 199\left(2.79 \mathrm{~A}^{\circ}\right)$. Likewise, compound 4 f interacted through three hydrogen bonds as follows: (i) $\mathrm{SO}_{2}$ with His94 (2.86 $\mathrm{A}^{\circ}$ ), (ii) $\mathrm{SO}_{2}$ with His96 (3.38 $\left.\mathrm{A}^{\circ}\right)$, and (iii) $\mathrm{SO}_{2}$ with Thr199 (2.84 $\mathrm{A}^{\circ}$ ). Compounds $\mathbf{4 b}$ and $\mathbf{4 f}$ showed binding interaction through the $\mathrm{CH}_{3} \mathrm{SO}_{2}$ group with three or four hydrogen bonds. In contrast, indomethacin showed poor binding with $\mathrm{COX}-2$ with one hydrogen bond, this confirms that the more selectivity of synthesized compounds than indomethacin toward COX-2 receptor.

Compounds $\mathbf{4 b}$ and $\mathbf{4 f}$ were highly bound to the COX-2 receptor (affinity in $\mathrm{kcal} / \mathrm{mol}$ is -6.56 to -5.67 ) in comparison with valdecoxib $(-4.52 \mathrm{kcal} / \mathrm{mol})$. Finally, these docking results were well-matched with the in vitro COX-2 inhibition assays and show that the selectivity of compounds $\mathbf{4 b}$ and $\mathbf{4 f}$ against COX-2 isozyme possibly due to the presence of $\mathrm{SO}_{2} \mathrm{Me}$ as $\mathrm{COX}-2$ pharmacophore (Figs. 3-6). 
Table 3. Molecular modeling data for compounds $\mathbf{4 b}$, $\mathbf{4 f}$, and Valdecoxib during docking in COX-2 (PDB ID: 2AW1) active site.

\begin{tabular}{|c|c|c|c|c|c|c|}
\hline \multirow{3}{*}{ Compound } & \multicolumn{6}{|c|}{ COX-2 } \\
\hline & \multirow[t]{2}{*}{$\begin{array}{c}\text { Affinity } \\
\text { (kcal/mol) }\end{array}$} & \multirow{2}{*}{$\begin{array}{c}\begin{array}{c}\text { Affinity } \\
\text { kcal/mol }\end{array} \\
-1.6\end{array}$} & \multicolumn{2}{|c|}{$\begin{array}{c}\text { Distance (in } \mathbf{A}^{0} \text { ) } \\
\text { from main residue }\end{array}$} & \multirow{2}{*}{$\begin{array}{c}\begin{array}{c}\text { Functional } \\
\text { group }\end{array} \\
-\mathrm{SO}_{2}\end{array}$} & \multirow{2}{*}{$\begin{array}{l}\text { Interaction } \\
\text { H-acceptor }\end{array}$} \\
\hline & & & 2.85 & His94 & & \\
\hline \multirow{4}{*}{$4 b$} & \multirow{4}{*}{-6.56} & -1.4 & 3.39 & His96 & $-\mathrm{SO}_{2}$ & $\mathrm{H}$-acceptor \\
\hline & & -0.7 & 3.35 & Thr199 & $-\mathrm{SO}_{2}$ & $\mathrm{H}$-acceptor \\
\hline & & -1.4 & 2.79 & Thr199 & $-\mathrm{SO}_{2}$ & H-acceptor \\
\hline & & -1.1 & 2.86 & His94 & $-\mathrm{SO}_{2}$ & $\mathrm{H}$-acceptor \\
\hline \multirow[t]{2}{*}{$4 \mathrm{f}$} & \multirow[t]{2}{*}{-5.67} & -1.2 & 3.38 & His96 & $-\mathrm{SO}_{2}$ & H-acceptor \\
\hline & & -0.8 & 2.84 & Thr199 & $-\mathrm{SO}_{2}$ & $\mathrm{H}$-acceptor \\
\hline \multirow[t]{3}{*}{ Iindomethacin } & \multirow[t]{3}{*}{-5.88} & -0.7 & 3.52 & Thr199 & $-\mathrm{OH}$ & H-donor \\
\hline & & -1.3 & 2.74 & His119 & $-\mathrm{NH}_{2}$ & H-donor \\
\hline & & -1.5 & 3.46 & Thr199 & $-\mathrm{NH}_{2}$ & H-donor \\
\hline \multirow[t]{3}{*}{ Valdecoxib } & \multirow[t]{3}{*}{-4.52} & -0.7 & 3.12 & Leu198 & $-\mathrm{SO}_{2}$ & $\mathrm{H}$-acceptor \\
\hline & & -3.3 & 2.77 & Thr199 & $-\mathrm{SO}_{2}$ & $\mathrm{H}$-acceptor \\
\hline & & -0.0 & 2.89 & His94 & $-\mathrm{NH}_{2}$ & $\mathrm{H}$-acceptor \\
\hline
\end{tabular}

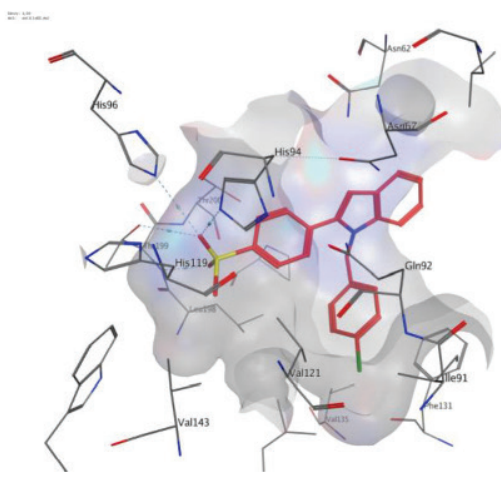

(a)

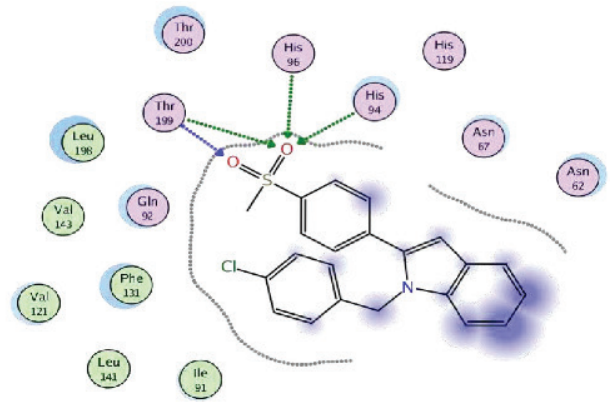

( Val

Figure 3. Binding of the compound $\mathbf{4 b}$ inside COX-2 active site: (a) The 3D proposed binding mode inside the active site of COX-2; (b) 2D interaction.

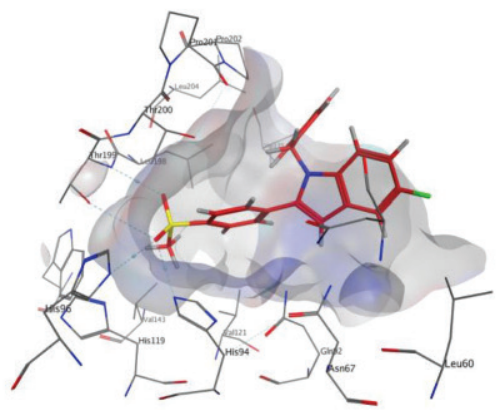

(a)

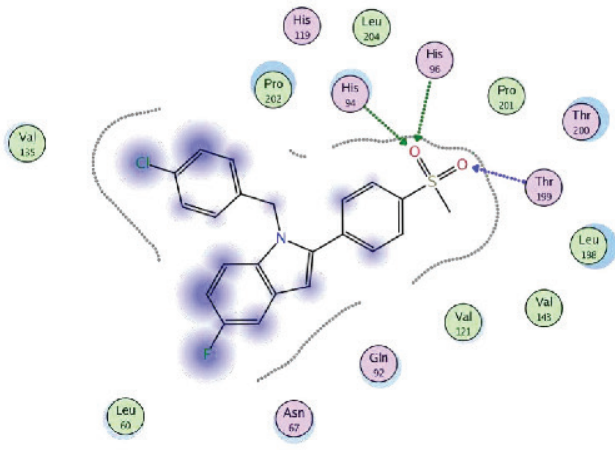

(b)

Figure 4. Binding of the compound $\mathbf{4 f}$ inside COX-2 active site: (a) The 3D proposed binding mode inside the active site of COX-2; (b) 2D interaction. 


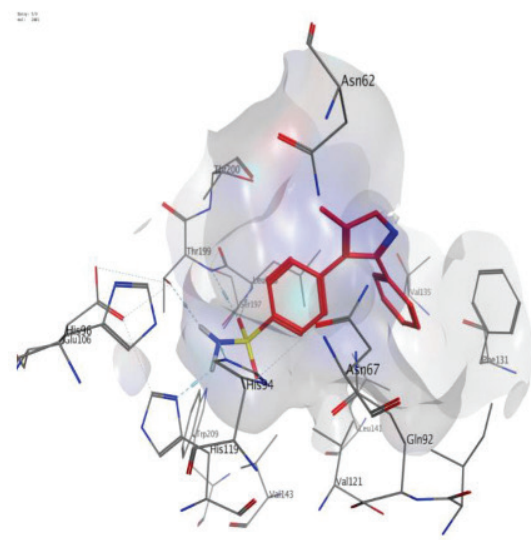

(a)

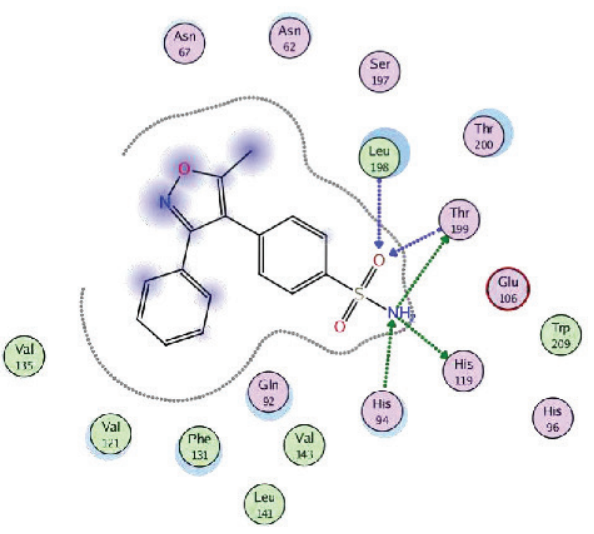

(b)

Figure 5. Binding of the compound Valdecoxib inside COX-2 active site: (a) The 3D proposed binding mode inside the active site of COX-2; (b) 2D interaction.
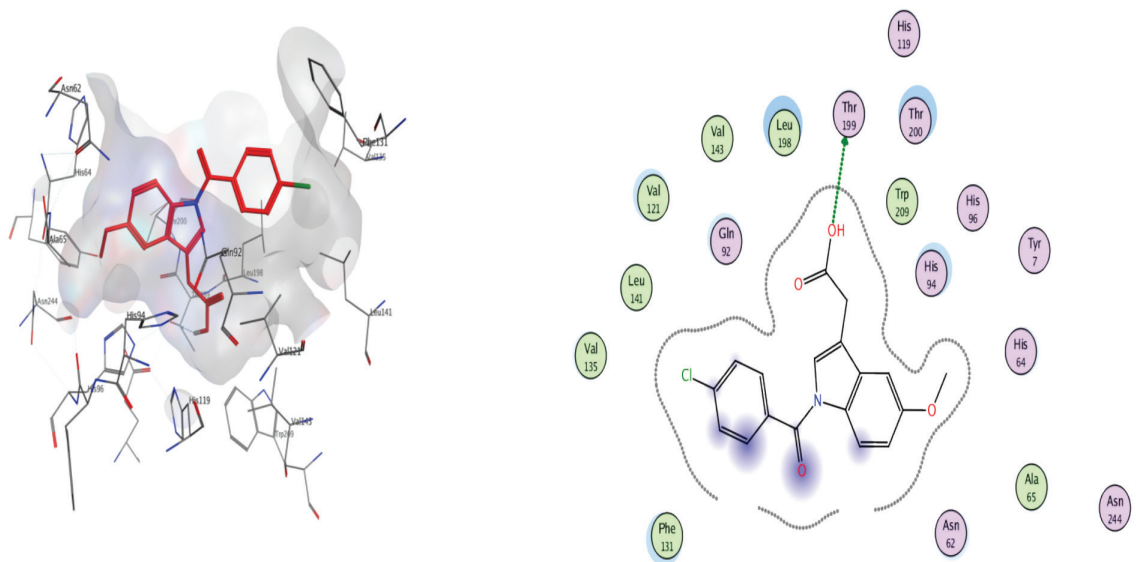

Figure 6. Binding of the compound Indomethacin inside COX-2 active site: (a) The 3D proposed binding mode inside the active site of COX-2; (b) 2D interaction.

\section{CONCLUSION}

The synthesized compounds $(\mathbf{4 a - f})$ as indomethacin analogs are biologically retained its anti-inflammatory activity. In vitro COX inhibitory activity assay showed that all prepared compounds were highly selective toward COX-2 receptor $(\mathrm{SI}=30.35-107.63)$ more than indomethacin $(\mathrm{SI}=0.079)$. On the other hand, in vivo anti-inflammatory activity studies showed good anti-inflammatory activity, especially $\mathbf{4 b}, \mathbf{4 d}$, and $\mathbf{4 f}(90.5 \%, 75.6 \%$, and $81.1 \%$, respectively) in comparison with indomethacin (87.7\%), In addition to the molecular modeling studies that ensure in vitro COX inhibition evaluation results. Molecular modeling of the compound $\mathbf{4 b}, \mathbf{4 f}$ showed excellent fitting to a COX-2 enzyme $(-6.56$ and $-5.67 \mathrm{kcal} /$ mol, respectively) which were interacted through hydrogen bonds in comparison with valdecoxib $(-4.52 \mathrm{kcal} / \mathrm{mol})$ with five hydrogens binding interactions.

\section{CONFLICT OF INTEREST}

There are no conflicts of interest.

\section{FUNDING}

Nil.

\section{REFERENCES}

Abdelazeem AH, Abdelatef SA, El-Saadi MT, Omar HA, Khan SI, McCurdy CR, El-Moghazy SM. Novel pyrazolopyrimidine derivatives targeting COXs and iNOS enzymes: design, synthesis and biological evaluation as potential anti-inflammatory agents. Eur J Pharm Sci, 2014; 62:197-211.

Abdellatif KR, Abdelgawad MA, Elshemy HA, Alsayed SS. Design, synthesis and biological screening of new 4-thiazolidinone derivatives with promising COX-2 selectivity, anti-inflammatory activity and gastric safety profile. Bioorg Med Chem, 2016a; 64:1-12.

Abdellatif KR, Lamie PF, Omar HA. 3-Methyl-2-phenyl-1substituted-indole derivatives as indomethacin analogs: design, synthesis and biological evaluation as potential anti-inflammatory and analgesic agents. J Enzyme Inhib Med Chem, 2016b;31:318-24.

Bandgar BP, Sarangdhar RJ, Viswakarma S, Ahamed FA. Synthesis and biological evaluation of orally active prodrugs of indomethacin. J Med Chem, 2011; 54:1191-201.

Brune K, Patrignani P. New insights into the use of currently available non-steroidal anti-inflammatory drugs. J Pain Res, 2015; 8:105.

Bruno A, Tacconelli S, Patrignani P. Variability in the response to non-steroidal anti-inflammatory drugs: mechanisms and perspectives. Basic Clin Pharmacol Toxicol, 2014; 114:56-63.

Chowdhury MA, Huang Z, Abdellatif KR, Dong Y, Yu G, Velázquez CA, Knaus EE. Synthesis and biological evaluation of indomethacin analogs possessing a N-difluoromethyl-1, 2-dihydropyrid-2-one ring system: 
a search for novel cyclooxygenase and lipoxygenase inhibitors. Bioorg Med Chem Lett, 2010; 20:5776-80.

Di Fiore A, Pedone C, D'Ambrosio K, Scozzafava A, De Simone G, Supuran CT. Carbonic anhydrase inhibitors: valdecoxib binds to a different active site region of the human isoform II as compared to the structurally related cyclooxygenase II 'selective' inhibitor celecoxib. Bioorg Med Chem Lett, 2006; 16:437-42.

Harirforoosh S, Asghar W, Jamali F. Adverse effects of nonsteroidal antiinflammatory drugs: an update of gastrointestinal, cardiovascular and renal complications. J Pharm Pharm Res, 2014; 16:821-47.

Jutti Levita AN, Mutholib A, Ibrahim S. Andrographolide inhibits COX-2 expression in human fibroblast cells due to its interaction with arginine and histidine in cyclooxygenase site. J J Appl Sci, 2010; $10: 1481-4$.

Kaur J, Bhardwaj A, Huang Z, Knaus EE. N-1 and C-3 substituted indole Schiff bases as selective COX-2 inhibitors: synthesis and biological evaluation. Bioorg Med Chem Lett, 2012; 22:2154-9.

Kirkby NS, Chan MV, Zaiss AK, Garcia-Vaz E, Jiao J, Berglund LM, Verdu EF, Ahmetaj-Shala B, Wallace JL, Herschman HR, Gomez MF. Systematic study of constitutive cyclooxygenase-2 expression: role of NF-kB and NFAT transcriptional pathways. Proc Natl Acad Sci, 2016; 113:434-9.

Lakshman TR, Deb J, Paine TK. Anti-inflammatory activity and enhanced COX-2 selectivity of nitric oxide-donating zinc (ii)-NSAID complexes. Dalton Trans, 2016; 45:14053-7.

Pathak RK, Marrache S, Choi JH, Berding TB, Dhar S. The prodrug platin-A: simultaneous release of cisplatin and aspirin. Angew Chem Int Ed, 2014; 53:1963-7.

Pountos I, Georgouli T, Calori GM, Giannoudis PV. Do nonsteroidal anti-inflammatory drugs affect bone healing? A critical analysis. Sci World J, 2012; 2012:14.

Raju D, Basavaraju Y. Synthesis of new tetralone ester intermediates for podophyllotoxin analogues. Pure Appl Chem, 2013; 1:43-9.
Regulski M, Regulska K, Prukała W, Piotrowska H, Stanisz B, Murias M. COX-2 inhibitors: a novel strategy in the management of breast cancer. Drug Discov Today, 2016; 21:598-615.

Sostres C, Gargallo CJ, Lanas A. Nonsteroidal anti-inflammatory drugs and upper and lower gastrointestinal mucosal damage. Arthritis Res Ther, 2013; 15:S3.

Van Breemen RB, Tao Y, Li W. Cyclooxygenase-2 inhibitors in ginger (Zingiber officinale). Fitoterapia, 2011; 82:38-43.

Wehling M. Non-steroidal anti-inflammatory drug use in chronic pain conditions with special emphasis on the elderly and patients with relevant comorbidities: management and mitigation of risks and adverse effects. Eur J Clin Pharmacol, 2014; 70:1159-72.

Yu B, Liu A-H, He L-N, Li B, Diao Z-F, Li Y-N. Catalyst-free approach for solvent-dependent selective oxidation of organic sulfides with oxone. Green Chem, 2012; 14:957-62.

Zarghi A, Tahghighi A, Soleimani Z, Daraie B, Dadrass OG, Hedayati M. Design and synthesis of some 5-substituted-2-(4-(azido or methylsulfonyl) phenyl)-1H-indole derivatives as selective cyclooxygenase (COX-2) inhibitors. Sci Pharm, 2008; 76:361-76.

\section{How to cite this article:}

Shaker AMM, Abdelall EKA, Abdellatif KRA, AbdelRahman HM. Design, synthesis and biological evaluation of 2-(4-(methylsulfonyl)phenyl) indole derivatives with promising COX-2 inhibitory activity. J App Pharm Sci, 2018; 8(11): 001-008. 